\title{
Anaerobic co-digestion of cork based oil sorbent and cow manure or sludge
}

\author{
A.J. Cavaleiro, T.M. Neves, A.P. Guedes \& M.M. Alves \\ Centre of Biological Engineering, University of Minho, Braga, Portugal \\ P. Pinto \& S.P. Silva \\ Corticeira Amorim, S.G.P.S., S.A., S. Paio de Oleiros, Santa Maria da Feira, Portugal \\ D.Z. Sousa \\ Laboratory of Microbiology, Wageningen University, Wageningen, The Netherlands \\ Centre of Biological Engineering, University of Minho, Braga, Portugal
}

\begin{abstract}
Cork, a material with great economic, social and environmental importance in Portugal, is also a good oil sorbent that can be used in the remediation of oil spills. The oil-impregnated cork can be easily removed, but requires further treatment. In the case of vegetable oil spills, anaerobic digestion may be a potential solution. This study aims to evaluate the effect of adding cork contaminated with sunflower oil as co-substrate in anaerobic digestion processes. Biodegradability assays were prepared with cow manure or sludge from a wastewater treatment plant, in the presence of five concentrations of oil-contaminated cork, between 200 and $1000 \mathrm{mg} \cdot \mathrm{L}^{-1}$ as COD. Maximum cumulative methane production increased with the amount of oily cork up to $41 \%$ and $101 \%$ in the assays with manure and sludge, respectively. Sporadic addition of cork contaminated with vegetable oil during anaerobic digestion of manure or sludge increases significantly the methane production of these processes.
\end{abstract}

\section{INTRODUCTION}

Vegetable oil spills, although less perceived than mineral oil spills, cause deleterious effects on ecosystems and present serious environmental problems (Mudge 1995, Li et al. 2007). Acute and chronic contamination of marine environments has been reported, causing depletion of dissolved oxygen from the water column, and mortality of fish, birds and sessile animals (Mudge 1995, Li et al. 2007, EPA 2011). While poorly documented, these accidents occur frequently during storage and transportation of oils (Mudge 1995, EPA 2011), and may also represent an important source of contamination in oil refineries.

The use of sorbent materials is a fast and effective strategy for oil removal from contaminated sites, rapidly decreasing the environmental damage of oil spills. Maximum sorption capacity, prolonged oil retention, biodegradability or potential reuse of the sorbent material are factors that determine the choice of a sorbent. Sorbents may be inorganic (e.g. clay, vermiculite, diatomite) or organic, from natural or synthetic origin. Organic synthetic products, such as polypropylene or polyurethane foam, have high sorption capacity, but are not renewable or biodegradable (Teas et al. 2001).

The use of cork as natural sorbent has been promoted by Corticeira Amorim, with its commercial product CorkSorb. This product has a maximum oil absorption capacity of $9.43 \mathrm{~L} \cdot \mathrm{kg}^{-1}$, which is higher than that of mineral sorbents, and similar or even greater than other organic sorbents such as peat, cellulose or polypropylene. Absorption occurs by capillarity in approximately $15 \mathrm{~s}$, and the oil is retained in the cork cells for months. The hydrophobic characteristics of the CorkSorb 
products are advantageous when spills occur in aquatic environments or wet floors (Silva \& Reis 2007, Corticeira Amorim 2009).

The oil-impregnated cork is easily removed from the oil spill site, but has to be treated later. One of the possible treatments for the oily cork waste, and currently most used, is incineration. Another possible alternative is anaerobic digestion, which has the advantage of coupling waste treatment with energy production in the form of biogas (Esposito et al. 2012). High biogas production can be expected from oils and fats, and the addition of lipid-rich wastes to anaerobic digestion processes was shown to significantly increase the net energy balance of these systems (Alves et al. 2009, Neves et al. 2009a). The anaerobic treatment of two or more wastes is called co-digestion, and presents several technological and economic advantages, provided the mixture of wastes is carefully controlled to avoid inhibition (Neves et al. 2009a, Alvarez et al. 2010). The digestate produced in the co-digestion processes may be used in agriculture, after stabilization or composting (Álvarez et al. 2010). The presence of cork in the digestate may improve its characteristics as a soil conditioner.

In this work, cork contaminated with sunflower oil was added as co-substrate in anaerobic digestion processes, and the effect on biogas production was assessed.

\section{MATERIALS AND METHODS}

\subsection{Oil-contaminated cork waste}

Thermal treated hydrophobic cork granules $(0.3-1 \mathrm{~mm})$ were provided by Corticeira Amorim. Cork was contaminated in the laboratory by adding $5 \mathrm{~kg}$ of commercial sunflower oil per $\mathrm{kg}$ of cork, which corresponds to approximately half of its maximum absorption capacity (Pintor et al. 2012). Total and volatile solids of the non-contaminated cork were 96 and $92 \%$, respectively. Chemical oxygen demand (COD) of the commercial oil was $1.6 \pm 0.1 \mathrm{~kg} \cdot \mathrm{kg}^{-1}$. Long chain fatty acids (LCFA) were analyzed after promoting hydrolysis of the oil, based on the methods of Brandl et al. (1988) and Neves et al. (2009b). LCFA content of the commercial sunflower oil was $32 \%$ linoleic acid (C18:2), 23\% oleic acid (C18:1), 22\% stearic acid (18:0), 21\% palmitic acid (C16:0) and 3\% other LCFA.

\subsection{Specific methanogenic activity of manure and sewage sludge}

Manure from a cattle production unit, or secondary sludge from a wastewater treatment plant in northern Portugal, were used in the biodegradability assays. The specific methanogenic activity of these organic wastes was evaluated in closed bottles prepared with a volatile solids content of approximately $3 \mathrm{~g} \cdot \mathrm{L}^{-1}$. Acetate $\left(30 \mathrm{mmol} \cdot \mathrm{L}^{-1}\right)$ or $\mathrm{H}_{2} / \mathrm{CO}_{2}(80: 20 \%$, total pressure of $2 \mathrm{bar})$ were added as direct substrates for the methanogens. A pressure transducer was used to measure changes in the pressure over time. Simultaneously, control tests were conducted without substrate addition, or pressurized with $\mathrm{N}_{2} / \mathrm{CO}_{2}$ (80:20\%, total pressure of 2 bar) (Colleran et al. 1992). Bicarbonate buffered medium was used, with sodium sulfide $\left(0.8 \mathrm{mmol} \cdot \mathrm{L}^{-1}\right)$ as reducing agent and resazurin as redox indicator. All the assays were performed in triplicate, and were incubated in the dark, at $37^{\circ} \mathrm{C}$ under a rotation speed of $120 \mathrm{~min}^{-1}$. The specific methanogenic activity was calculated by dividing the initial slope of the methane production curve by the amount of volatile solids (VS) in the bottle at the end of the assay $\left(\mathrm{mL} \mathrm{g}^{-1} \cdot\right.$ day $\left.^{-1}\right)$. Relatively low activity values were obtained for the manure, i.e. $29 \pm 4$ and $279 \pm 12 \mathrm{~mL} \mathrm{~g}^{-1}$. day ${ }^{-1}$ in the presence of acetate or $\mathrm{H}_{2} / \mathrm{CO}_{2}$, respectively. For the sewage sludge, acetoclastic and hydrogenotrophic activity were $13 \pm 1$ and $0 \mathrm{~mL}^{-1} \cdot$ day $^{-1}$, respectively.

\subsection{Biodegradability assays}

Biodegradability assays were performed under strict anaerobic conditions in closed vials in which the oil-contaminated cork waste was incubated in the presence of cow manure or sewage sludge 
Table 1. Experimental conditions applied in the biodegradability assays.

\begin{tabular}{lccc}
\hline Code & $\begin{array}{l}\text { Cork } \\
\left(\mathrm{mg} \cdot \mathrm{L}^{-1}\right)\end{array}$ & $\begin{array}{l}\text { Oil COD concentration } \\
\left(\mathrm{mg} \cdot \mathrm{L}^{-1}\right)\end{array}$ & $\begin{array}{l}\text { Oil concentration } \\
\left(\mathrm{mg} \cdot \mathrm{L}^{-1}\right)\end{array}$ \\
\hline Blk & 0 & 0 & 0 \\
CO-200 & 26 & 200 & 128 \\
CO-400 & 51 & 400 & 256 \\
CO-600 & 77 & 600 & 385 \\
CO-800 & 103 & 800 & 513 \\
CO-1000 & 128 & 1000 & 641 \\
C-200 & 26 & 0 & 0 \\
C-400 & 51 & 0 & 0 \\
C-600 & 77 & 0 & 0 \\
C-800 & 103 & 0 & 0 \\
C-1000 & 128 & 0 & 0 \\
O-200 & 0 & 200 & 128 \\
O-400 & 0 & 400 & 256 \\
O-600 & 0 & 600 & 385 \\
O-800 & & 800 & 513 \\
O-1000 & 0 & 1000 & 641 \\
\hline
\end{tabular}

Blk - blank; CO - cork + oil; C - cork; O - oil.

(mass concentration, expressed as SV, of $3 \mathrm{~g} \cdot \mathrm{L}^{-1}$ ). The conditions applied are summarized in Table 1.

Five different concentrations of oil-contaminated cork waste were tested ( $\mathrm{CO}$ code in Table 1). As described in section 2.1, the amount of oil and cork are proportional, and thus CO tests were prepared with increasing concentrations of both oil and cork. In parallel, blank assays were performed in the absence of contaminated cork residue, i.e. containing only manure or sludge (Blk in Table 1). Control experiments were also prepared with (i) non-contaminated cork granules ( $C$ in Table 1), and (ii) commercial vegetable oil without cork ( $O$ in Table 1). These two sets of controls were prepared to evaluate potential inhibitory effects or stimulation of biogas production, due to the individual presence of cork or oil. The five control assays performed with non-contaminated cork were prepared with the same amounts of cork added to the different biodegradability tests (CO assays). In the controls with oil, the same five concentrations of oil used in CO assays were tested.

The assays were prepared with bicarbonate buffered basal medium supplemented with salts and vitamins, as described by Angelidaki et al. (2009). All assays were performed in triplicate, and the flasks were incubated at $37^{\circ} \mathrm{C}$ without stirring. Methane production was quantified during the biodegradation tests by gas chromatography (GC). Methane yields (in \%) were calculated after discounting the value of the blanks, through the ratio between the maximum cumulative methane production obtained in each test and the expected theoretical value, which was calculated from the LCFA composition of the added oil. The statistical significance of differences detected in the maximum cumulative methane production values was assessed using analysis of variance (ANOVA) single factor. Statistical significance was set at $\mathrm{P}<0.05$. Volatile fatty acids were analyzed at the beginning and end of the tests. At the end, medium chain fatty acids (MCFA) and LCFA were also quantified after freeze-drying the content of the bottles.

\section{RESULTS AND DISCUSSION}

The use of cork as oil absorbent in oil spills is expected to generate modest amounts of oilcontaminated cork waste, at a relatively low frequency. Therefore, this waste can be added as a 

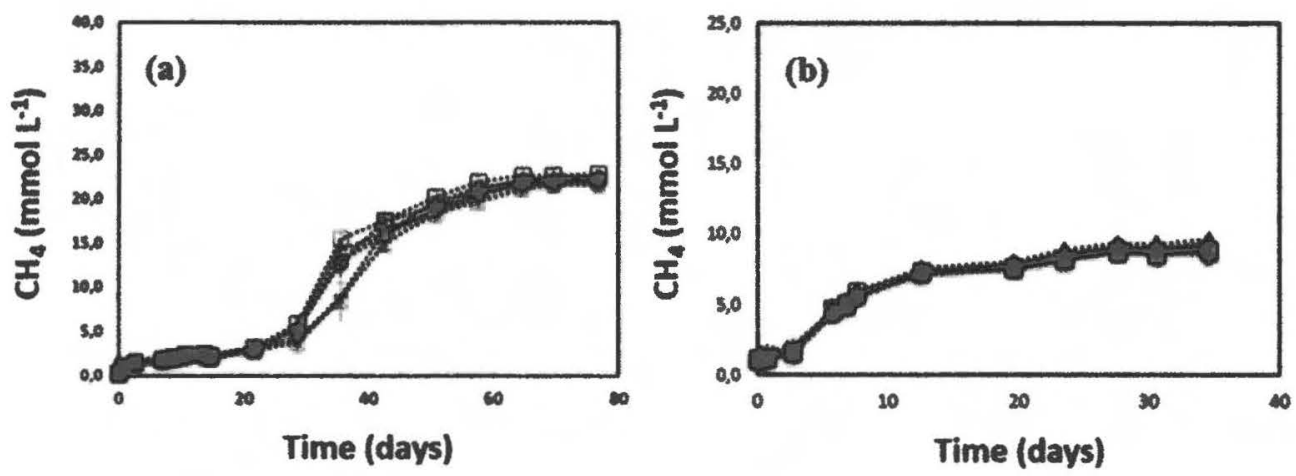

Figure 1. Cumulative methane production in the controls where non-contaminated cork was co-digested with

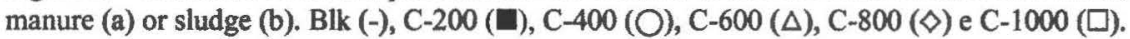

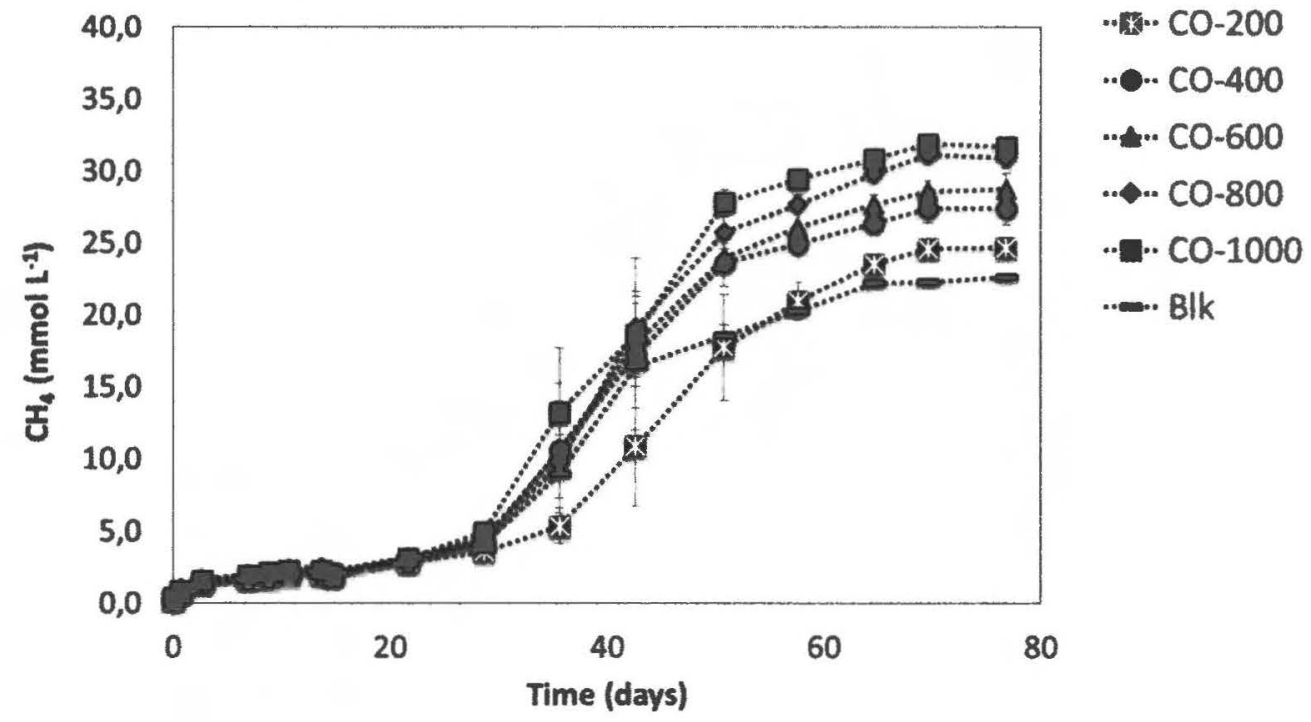

Figure 2. Cumulative methane production in the assays with manure and oil-contaminated cork.

co-substrate to ongoing anaerobic digestion processes. Biodegradation of the oil may improve the energy yield of the process, or oil can be inhibitory to the anaerobic microorganisms. Specifically the methanogens have been reported as very sensitive to LCFA toxicity (Lalman \& Bagley 2002). Moreover, the potential presence of aromatic compounds in the cork granules can also inhibit the microbial activity. Control trials ( $\mathrm{C}$ and $\mathrm{O}$ ) were set to assess these effects.

Comparing to the blank assays (Blk), no significant differences were observed in methane production when non-contaminated cork was added to both experiments with manure or sludge (Fig. 1). These results indicate that cork did not influenced the anaerobic degradation process.

The ability of the complex microbial communities, present in the manure or sludge, to convert the sunflower oil to methane was confirmed in the control tests performed with oil (O). Methane yields varied between $32-55 \%$ and no inhibition was observed with the increase of oil concentrations (data not shown). The absence of free fatty acids at the end of the tests suggest that the relatively low methane yields are probably related with limitations in the hydrolysis step. 


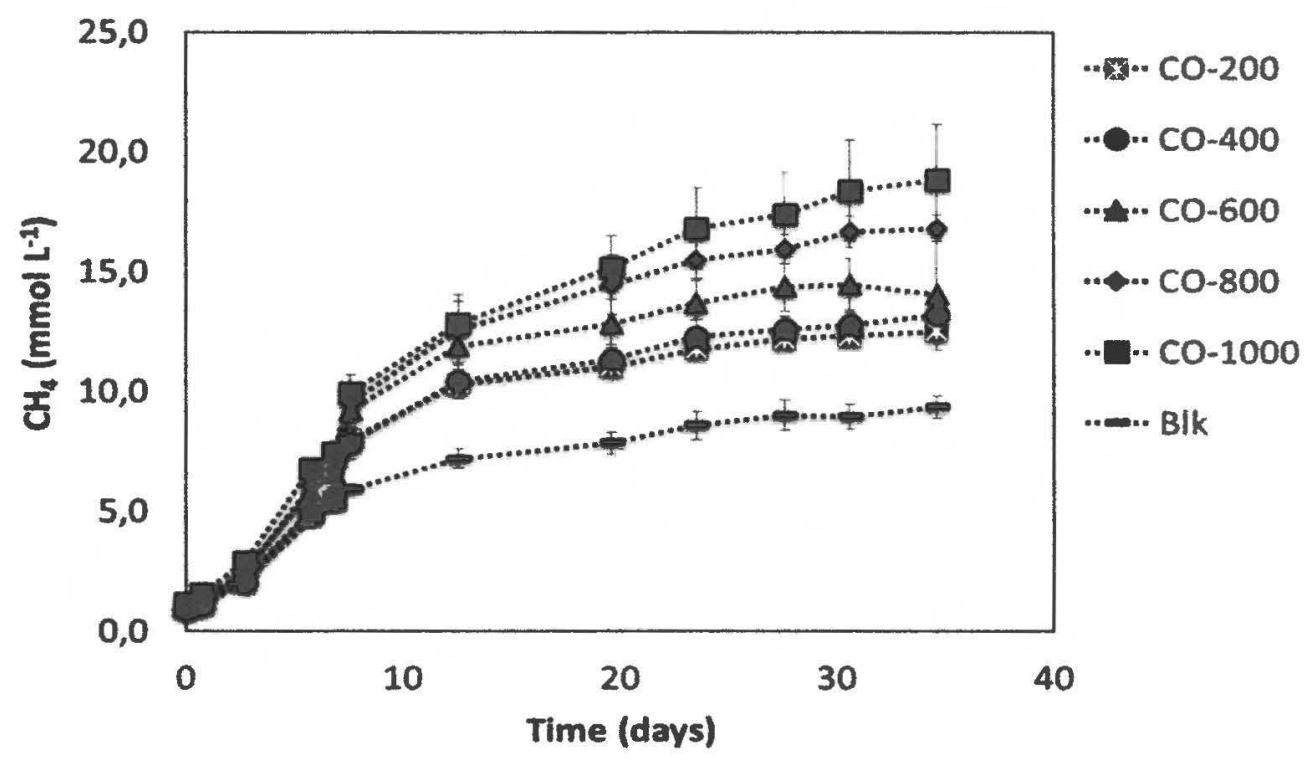

Figure 3. Cumulative methane production in the assays with sewage sludge and oil-contaminated cork.

In the assays performed with oil-contaminated cork, maximum cumulative methane production increased significantly $(\mathrm{p}<0.01)$ in comparison with the blanks (Blk). This increase was proportional to the amount of waste added (Figs. $2-3$ ) and reached a maximum value of $41 \%$ and $101 \%$ in CO-1000 assays with manure and sludge, respectively. Thus, it can be concluded that sporadic addition of oil-contaminated cork during the anaerobic treatment of manure or sludge improves the methane production of these processes.

\section{CONCLUSIONS}

Addition of oil-contaminated cork had a positive effect on the maximum cumulative methane production obtained in the anaerobic digestion of manure or sewage sludge. This effect was proportional to the amount of oil-impregnated cork added, and reached maximum values of $41 \%$ in the test with manure and $101 \%$ in the assay with sewage sludge. The use of this approach allows the recovery of the energetic potential of the waste lipids present in the oil-contaminated cork obtained from the remediation of oil spills.

\section{ACKNOWLEDGMENTS}

The European Regional Development Fund - ERDF, through the Operational Program Thematic Factors of Competitiveness - COMPETE, and the Portuguese Foundation for Science and Technology (FCT), in the frame of projects FCOMP01-0124-FEDER-014784 (FCT: PTDC/EBBEBI/1 14364/2009) e FCOMP-010124-FEDER-027917 (FCT: PTDC/AAG-TEC/3428/2012), are acknowledged. The authors also thank to the FCT Strategic Project PEst-OE/EQB/LA0023/2013 and the Project "BioEnv - Biotechnology and Bioengineering for a sustainable world", REF. NORTE-07-0124-FEDER-000048", co-funded by the Programa Operacional Regional do Norte (ON.2 - O Novo Norte), QREN, FEDER. 


\section{REFERENCES}

Álvarez, J.A, Otero, L. \& Lema, J.M. 2010. A methodology for optimising feed composition for anaerobic co-digestion of agro-industrial wastes. Bionesource Technology 101: 1153-1158.

Alves, M.M., Pereira, M.A., Sousa, D.Z., Cavaleiro, A.J., Picavet, M., Smidt, H. \& Stams, A.J. 2009. Waste lipids to energy: how to optimize methane production from long-chain fatty acids (LCFA). Microbial Biotechnology 2: 538-550.

Angelidaki, I., Alves, M., Bolzonella, D., Borzacconi, L., Campos, J.L., Guwy, A.J., Kalyuzhnyi, S., Jenicek, P. \& van Lier, J.B. 2009. Defining the biomethane potential (BMP) of solid organic wastes and energy crops: a proposed protocol for batch assays. Water Science \& Technology 59: 927-934.

Brandl, H., Gross, R.A., Lenz, R.W. \& Fuller, R.C. 1988. Pseudomonas oleovorans as a source of poly ( $\beta$-hydroxyalkanoates) for potential applications as biodegradable polyesters. Applied and Environmental Microbiology 54: 1977-1982.

Colleran, E., Concannon, F., Golden, T., Geoghegan, F., Crumlish, B., Killilea, E., Henry, M. \& Coates, J. 1992. Use of methanogenic activity tests to characterize anaerobic sludges, screen for anaerobic biodegradability and determine toxicity thresholds against individual anaerobic trophic groups and species. Water Science and Technology 25: 31-40.

Corticeira Amorim, S.G.P.S., S.A. 2009. CorkSorb, sustainable absorbents. http://www.corkSorb.com/index. php, accessed on 8 April 2015.

U.S. Environmental Protection Agency 2011. Oil spills. htpp://www.epa.gov/oilspill, accessed on 8 April 2015.

Esposito, G., Frunzo, L., Giordano, A., Liotta, F., Panico, A. \& Pirozzi, F. 2012. Anaerobic co-digestion of organic wastes. Reviews in Environmental Science and Biotechnology 11:325-341.

Lalman, J. \& Bagley, D.M. 2002. Effects of C18 long chain fatty acids on glucose, butyrate and hydrogen degradation. Water Research 36: 3307-3313.

Li, Z., Lee, K., Cobanli, S.E., King, T., Wrenn, B.A., Doe, K.G., Jackman, P.M. \& Venosa, A.D. 2007. Assessment of sediment toxicity during anaerobic biodegradation of vegetable oil using Microtox and Hyalella azteca bioassays. Environmental Toxicology 22: 1-8.

Mudge, S.M. 1995. Deleterious effects from accidental spillages of vegetable oils. Spill Science \& Technology Bulletin 2: 187-191.

Neves, L., Oliveira, R. \& Alves, M.M. 2009a. Co-digestion of cow manure, food waste and intermittent input of fat. Bioresource Technology 100: 1957-1962.

Neves, L., Pereira, M.A., Mota, M. \& Alves, M.M. 2009b. Detection and quantification of long chain fatty acids in liquid and solid samples and its relevance to understand anaerobic digestion of lipids. Bioresource Technology 100: 91-96.

Pintor, A.M.A., Ferreira, C.I.A., Pereira, J.C., Correia, P., Silva, S.P., Vilar, V.J.P., Botelho, C.M.S. \& Boaventura, R.A.S. 2012. Use of cork powder and granules for the adsorption of pollutants: a review. Water Research 46: 3152-3166.

Silva, S.P. \& Reis, R.L. 2007. Meio de absorçãoladsorção à base de derivados de cortiça para absorção/adsorção de óleos. PT 103492.

Teas, Ch., Kalligeros, S., Zanikos, F., Stournas, S., Lois, E. \& Anastopoulos, G. 2001. Investigation of the effectiveness of absorbent materials in oil spills clean up. Desalination 140: 259-264. 